\title{
Front Matter: Volume 9523
}

, "Front Matter: Volume 9523," Proc. SPIE 9523, International Conference on Nano-Bio Sensing, Imaging, and Spectroscopy 2015, 952301 (8 July 2015); doi: $10.1117 / 12.2205215$

SPIE Event: International Conference on Nano-Bio Sensing, Imaging, and SPIE. Spectroscopy 2015, 2015, Jeju, Korea, Republic of 


\title{
PROGRESS IN BIOMEDICAL OPTICS AND IMAGING
}

\section{International Conference on Nano-Bio Sensing, Imaging, and Spectroscopy 2015}

\author{
Donghyun Kim \\ Min-Gon Kim \\ Seung-Han Park \\ Editors
}

\section{5-27 February 2015}

Jeju, Korea, Republic of

Organized by

The Optical Society of Korea

The Korean Sensors Society

The Korean BioChip Society

Sponsored by

SPIE

\section{Cosponsored by}

BK21 Plus/Institute of Physics and Applied Physics (Korea, Republic of) - Institute of Convergence

Science (Korea, Republic of) - Electronics and Telecommunications Research Institute (Korea, Republic of) - Gwangju Institute of Science and Technology (Korea, Republic of) • BK21 Plus/Graduate Program for Bio-Nano Fusion Technology (Korea, Republic of) • ERC Center for Integrated Human Sensing System (Korea, Republic of) • LG Innotek (Korea, Republic of)

Published by

SPIE

Volume 9523 
The papers included in this volume were part of the technical conference cited on the cover and title page. Papers were selected and subject to review by the editors and conference program committee. Some conference presentations may not be available for publication. The papers published in these proceedings reflect the work and thoughts of the authors and are published herein as submitted. The publisher is not responsible for the validity of the information or for any outcomes resulting from reliance thereon.

Please use the following format to cite material from this book:

Author(s), "Title of Paper," in International Conference on Nano-Bio Sensing, Imaging, and Spectroscopy 2015, edited by Donghyun Kim, Min-Gon Kim, Seung-Han Park, Proceedings of SPIE Vol. 9523 (SPIE, Bellingham, WA, 2015) Article CID Number.

ISSN: 1605-7422

ISBN: 9781628416794

Published by

SPIE

P.O. Box 10, Bellingham, Washington 98227-0010 USA

Telephone +1 3606763290 (Pacific Time) · Fax +1 3606471445

SPIE.org

Copyright (@ 2015, Society of Photo-Optical Instrumentation Engineers.

Copying of material in this book for internal or personal use, or for the internal or personal use of specific clients, beyond the fair use provisions granted by the U.S. Copyright Law is authorized by SPIE subject to payment of copying fees. The Transactional Reporting Service base fee for this volume is $\$ 18.00$ per article (or portion thereof), which should be paid directly to the Copyright Clearance Center (CCC), 222 Rosewood Drive, Danvers, MA 01923. Payment may also be made electronically through CCC Online at copyright.com. Other copying for republication, resale, advertising or promotion, or any form of systematic or multiple reproduction of any material in this book is prohibited except with permission in writing from the publisher. The CCC fee code is $1605-7422 / 15 / \$ 18.00$.

Printed in the United States of America.

Publication of record for individual papers is online in the SPIE Digital Library.

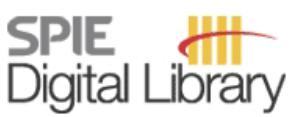

SPIEDigitalLibrary.org

Paper Numbering: Proceedings of SPIE follow an e-First publication model, with papers published first online and then in print. Papers are published as they are submitted and meet publication criteria. A unique citation identifier (CID) number is assigned to each article at the time of the first publication. Utilization of CIDs allows articles to be fully citable as soon as they are published online, and connects the same identifier to all online, print, and electronic versions of the publication. SPIE uses a six-digit CID article numbering system in which:

- The first four digits correspond to the SPIE volume number.

- The last two digits indicate publication order within the volume using a Base 36 numbering

system employing both numerals and letters. These two-number sets start with 00, 01, 02, 03, 04, $05,06,07,08,09,0 A, 0 B \ldots$. 0Z, followed by 10-1Z, 20-2Z, etc.

The CID Number appears on each page of the manuscript. The complete citation is used on the first page, and an abbreviated version on subsequent pages. 


\title{
Contents
}

\author{
vii Authors \\ ix Conference Committee \\ xiii Introduction
}

\section{MICRO-NANO BIOSENSING TECHNOLOGY}

952302 Smart point-of-care systems for molecular diagnostics based on nanotechnology: whole blood glucose analysis [9523-87]

\section{BIOMEDICAL APPLICATION OF OPTICAL BIOSENSORS I}

952303 High content cell-based assay for the inflammatory pathway (Invited Paper) [9523-173]

952304 Nanomaterial-based optical sensors for sensitive detection of heavy metal ions (Invited Paper) [9523-134]

952305 Graphene oxide-stimulated myogenic differentiation of C2C12 cells on PLGA/RGD peptide nanofiber matrices (Invited Paper) [9523-156]

\section{ADVANCED BIO-IMAGING}

952306 Principles and application of intrinsic Förster resonance energy transfer (iFRET) for label-free detection of native proteins (Invited Paper) [9523-33]

WAVEFRONT IMAGING TECHNIQUES

952307 Dark-field spectral imaging microscope for localized surface plasmon resonance-based biosensing (Invited Paper) [9523-71]

\section{NANOPLASMONIC SENSORS}

952308 Engineering optical near-fields for highly efficient surface-enhanced nanoplasmonics (Invited Paper) [9523-107]

952309 Dual-modal silica nanoprobes with surface enhanced Raman spectroscopic and fluorescent signals (Invited Paper) [9523-166] 
9523 OA Observation of Brownian motion of a micrometer-size bead in water by off-axis digital holographic microscopy [9523-68]

BIOMEDICAL APPLICATION OF OPTICAL BIOSENSORS II

$9523 \mathrm{OB} \quad$ A simple gel electrophoresis method for separating polyhedral gold nanoparticles (Invited Paper) [9523-113]

9523 OC Analysis of antifreeze protein activity using colorimetric gold nanosensors (Invited Paper) [9523-18]

IN-VIVO IMAGING FOR CLINICAL APPLICATIONS

9523 OD The gap-plasmonic effect induced on a silver nanoisland substrate for surface-enhanced Raman spectroscopy [9523-39]

9523 OE A fiber optic probe coupled low-cost CMOS-camera-based system for simultaneous measurement of oxy-, deoxyhemoglobin, and blood flow [9523-40]

\section{EMERGING TECHNOLOGIES FOR BIO-DETECTION}

$9523 \mathrm{OF}$ The study of structural color filter based on periodic nanohole arrays for bio-detection (Invited Paper) [9523-59]

POSTER SESSION: HIGH RESOLUTION IMAGING, SENSING, AND MANIPULATION

9523 OG High-contrast imaging of mycobacterium tuberculosis using third-harmonic generation microscopy [9523-12]

POSTER SESSION: OPTICAL IMAGING OF BIO-NANO SYSTEMS

$9523 \mathrm{OH} \quad$ Subdiffraction-limited axial imaging of live cells using linear nanoaperture arrays based on extraordinary transmission [9523-35]

POSTER SESSION: MOLECULAR OPTICAL BIOSENSING

$9523 \mathrm{Ol}$ Novel measurement of blood velocity profile using translating-stage optical method and theoretical modeling based on non-Newtonian viscosity model [9523-45] 
POSTER SESSION: LIGHT SCATTERING-BASED BIOMEDICAL IMAGING

9523 0J Highly sensitive immunoassay of anti-cyclic citrullinated peptide marker using surfaceenhanced Raman scattering detection [9523-109]

POSTER SESSION: BIOMEDICAL APPLICATION OF OPTICAL BIOSENSORS

9523 OK Integrated optical refractometer based on bend waveguide with air trench structure [9523-24]

$9523 \mathrm{OL}$ Probabilistic approach for sensing performances of localized surface plasmon resonance biosensors [9523-66]

POSTER SESSION: EMERGING TECHNOLOGIES FOR BIO-DETECTION

9523 OM NIR-emitting molecular-based nanoparticles as new two-photon absorbing nanotools for single particle tracking [9523-92]

$9523 \mathrm{ON}$ Solvent-modified ultrafast decay dynamics in conjugated polymer/dye labeled single stranded DNA [9523-129] 
Proc. of SPIE Vol. $9523952301-6$

Downloaded From: https://www.spiedigitallibrary.org/conference-proceedings-of-spie on 26 Apr 2023 Terms of Use: https://www.spiedigitallibrary.org/terms-of-use 


\section{Authors}

Numbers in the index correspond to the last two digits of the six-digit citation identifier (CID) article numbering system used in Proceedings of SPIE. The first four digits reflect the volume number. Base 36 numbering is employed for the last two digits and indicates the order of articles within the volume. Numbers start with 00, 01, 02, 03, 04, 05, 06, 07, 08, 09, OA, OB...0Z, followed by 10-1Z, 20-2Z, etc.

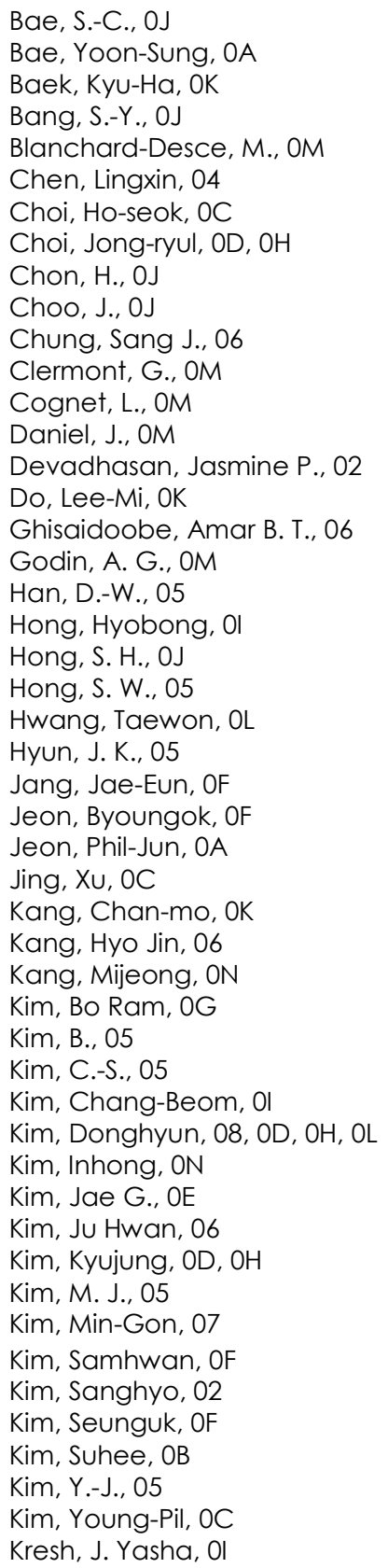

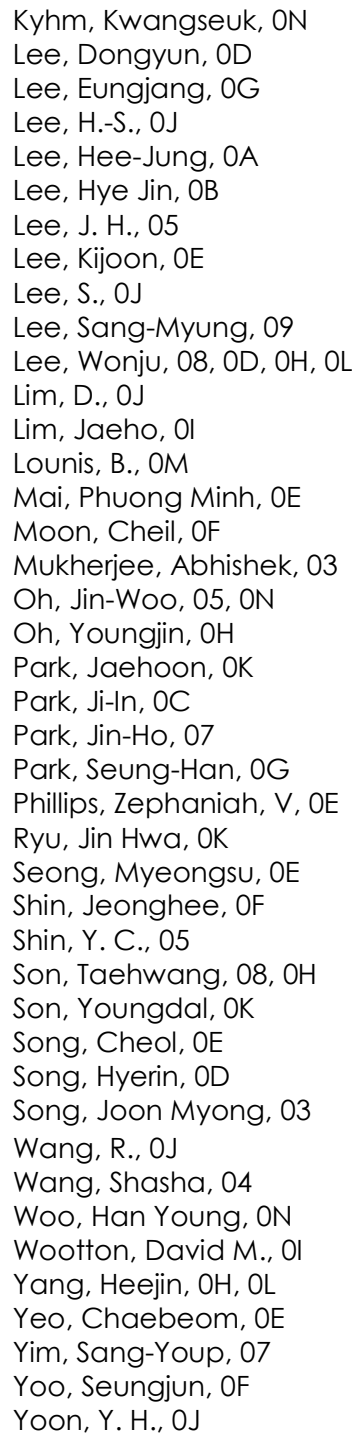


Proc. of SPIE Vol. $9523952301-8$

Downloaded From: https://www.spiedigitallibrary.org/conference-proceedings-of-spie on 26 Apr 2023 Terms of Use: https://www.spiedigitallibrary.org/terms-of-use 


\title{
Conference Committee
}

\author{
Conference Chair
}

Seung-Han Park, Yonsei University (Korea, Republic of)

Local Organizing Committee

Min-Gon Kim, Chair, Gwangju Institute of Science and Technology (Korea, Republic of)

Hyun Wook Kang, Pukyong University (Korea, Republic of)

Sangyoup Lee, Korea Institute of Science and Technology (Korea, Republic of)

Jae Chul Pyun, Yonsei University (Korea, Republic of)

Dong-Soo Shin, Hanyang University (Korea, Republic of)

Joo-Hiuk Son, University of Seoul (Korea, Republic of)

Sang-Youp Yim, Gwangju Institute of Science and Technology

(Korea, Republic of)

\section{Technical Program Committee}

Donghyun Kim, Chair, Yonsei University (Korea, Republic of)

Lionel Canioni, Université de Bordeaux (France)

Eunji Cheong, Yonsei University (Korea, Republic of)

Yong-Hoon Cho, Korea Advanced Institute of Science and Technology (Korea, Republic of)

Heon-Jin Choi, Yonsei University (Korea, Republic of)

Young-Geun Han, Hanyang University (Korea, Republic of)

Jae-Eun Jang, Daegu Gyeongbuk Institute of Science and Technology (Korea, Republic of)

Ki-Hun Jeong, Korea Advanced Institute of Science and Technology (Korea, Republic of)

Woonggyu Jung, Ulsan National Institute of Science and Technology (Korea, Republic of)

Chang Seok Kim, Pusan National University (Korea, Republic of)

Jeehyun Kim, Kyungpook National University (Korea, Republic of)

Tae Song Kim, Korea Institute of Science and Technology

(Korea, Republic of)

Hans-Joachim Krause, Forschungszentrum Jülich GmbH (Germany)

Sunghoon Kwon, Seoul National University (Korea, Republic of)

Kwangseuk Kyhm, Pusan National University (Korea, Republic of)

Jae Beom Lee, Pusan National University (Korea, Republic of)

Santiago Marco, Universidad de Barcelona (Spain)

Igor Meglinski, University of Otago (New Zealand) 
Cheil Moom, Daegu Gyeongbuk Institute of Science and Technology (Korea, Republic of)

Jwa-Min Nam, Seoul National University (Korea, Republic of)

Junghwan Oh, Pukyong National University (Korea, Republic of)

Kyunghwan Oh, Yonsei University (Korea, Republic of)

Wang-Yuhl Oh, Korea Advanced Institute of Science and Technology (Korea, Republic of)

YongKeun Park, Korea Advanced Institute of Science and

Technology (Korea, Republic of)

Krishna Persaud, University of Manchester (United Kingdom)

Giorgio Sberveglieri, Università degli di Brescia (Italy)

Joon Myong Song, Seoul National University (Korea, Republic of)

Seok Ho Song, Hanyang University (Korea, Republic of)

International Advisory Committee

Thierry Cardial, Centre National de la Recherche Scientifique (France)

Mun Y. Choi, University of Connecticut (United States)

Jaebum Choo, Hanyang University (Korea, Republic of)

James Grote, Air Force Research Laboratory (United States)

Rainer Herges, Christian-Albrechts-Universität zu Kiel (Germany)

Shin Won Kang, Kyungpook National University (Korea, Republic of)

Beop Min Kim, Korea University (Korea, Republic of)

Hak-Sung Kim, Korea Advanced Institute of Science and Technology

(Korea, Republic of)

Byeong Ha Lee, Gwangju Institute of Science and Technology

(Korea, Republic of)

Luke P. Lee, University of California, Berkeley (United States)

Seung-Han Park, Yonsei University (Korea, Republic of)

Eckhard Quandt, Christian-Albrechts-Universität zu Kiel (Germany)

Ki-Bong Song, Electronics and Telecommunications Research Institute (Korea, Republic of)

Din Ping Tsai, National Taiwan University (Taiwan)

Yi Zhang, Forschungszentrum Jülich GmbH (Germany)

Session Chairs

1 Advanced Bio Imaging

Joon Myong Song, Seoul National University (Korea, Republic of)

2 Biomedical Application of Optical Biosensors

Jaebum Choo, Hanyang University (Korea, Republic of)

3 Emerging Microscopic Techniques

YongKeun Park, Korea Advanced Institute of Science and

Technology (Korea, Republic of) 
$4 \quad$ Emerging Technologies for Bio-Detection

Cheil Moom, Daegu Gyeongbuk Institute of Science and Technology

(Korea, Republic of)

$5 \quad$ High-Resolution Imaging, Sensing, and Manipulation

Kwangseuk Kyhm, Pusan National University (Korea, Republic of)

$6 \quad$ In-Vivo Imaging for Clinical Applications

Ki-Hun Jeong, Korea Advanced Institute of Science and Technology

(Korea, Republic of)

$7 \quad$ Light Scattering-Based Biomedical Imaging

Yoon-Kyu Song, Seoul National University (Korea, Republic of)

$8 \quad$ Micro-Nano Biosensing Technology

Jiyun Kang, Korea Institute of Science and Technology

(Korea, Republic of)

$9 \quad$ Molecular Optical Bio-Sensing

Min-Gon Kim, Gwangju Institute of Science and Technology

(Korea, Republic of)

10 Neural Signal Electrical Measurements

Heon-Jin Choi, Yonsei University (Korea, Republic of)

11 Nano-Plasmonics Sensors

Young-Pil Kim, Hanyang University (Korea, Republic of)

12 Nanoscale Imaging and Detection Systems

Donghyun Kim, Yonsei University (Korea, Republic of)

13 Optical Coherence Tomography

Beop Min Kim, Korea University (Korea, Republic of)

14 Optical Fiber Sensors

Kyunghwan Oh, Yonsei University (Korea, Republic of)

15 Optical Imaging of Bio-Nano Systems

Kwangseuk Kyhm, Pusan National University (Korea, Republic of)

Chang Seok Kim, Pusan National University (Korea, Republic of)

16 Wavefront Imaging Techniques

Dug Young Kim, Yonsei University (Korea, Republic of) 
Proc. of SPIE Vol. 9523 952301-12

Downloaded From: https://www.spiedigitallibrary.org/conference-proceedings-of-spie on 26 Apr 2023 Terms of Use: https://www.spiedigitallibrary.org/terms-of-use 


\section{Introduction}

SPIE's 2nd International Conference on Nano-Bio Sensing, Imaging, and Spectroscopy (hereby NBSIS 2015) was organized by The Optical Society of Korea, The Korean Sensors Society, The Korea Bio Chip Society, and sponsored by SPIE. The principal goal of the NBSIS 2015 was to create a central forum for the presentation and discussion of the latest scientific and technical advances in the field of nano-bio based sensing, imaging, and spectroscopy, and their applications in research, development, and technical innovation. The meeting also provided an opportunity for suggesting development directions of technology along with information sharing and cooperation among researchers.

The NBSIS 2015 technical program consisted of four plenary talks, 82 oral presentations, and 42 poster presentations. We wish to thank every participant who presented high quality research results. The 22 papers in these proceedings were selected for publication after peer-review.

The next conference will be held in 2017 at the International Convention Center Jeju in Jeju Island, Korea. Your continued interest and concern will be greatly appreciated.

Seung-Han Park

General Chair of NBSIS 2015 
Proc. of SPIE Vol. 9523 952301-14

Downloaded From: https://www.spiedigitallibrary.org/conference-proceedings-of-spie on 26 Apr 2023 Terms of Use: https://www.spiedigitallibrary.org/terms-of-use 